\title{
Perdagangan Orang dalam Perspektif HAM dan Filsafat Hukum Islam
}

\author{
Fuad Mustafid \\ Universitas Islam Negeri Sunan Kalijaga, Yogyakarta - Indonesia \\ e-mail: fuadmustafid@gmail.com
}

\begin{abstract}
Human trafficking becomes a new phenomenon in modern century although its root have been existing since the ancient Greek era in the form of slavery. This crime currently occurs in many countries, as well as Indonesia. The government of every countries have tried to abolish the practice of human trafficking, but the results have been unsatisfied. Many people have become the victims of human trafficking and this phenomenon seems to continue to this day. This research aims to study about human trafficking phenomena based on human right perspective, legislation in Indonesia, and the philosophy of Islamic law. By this study, it is clear that the practice of human trafficking becomes a part of humanity crimes that contradicts to human right and Indonesian legislation, and it is also contradicted to Islamic Sharia because it emasculates the basic human right as a freedom human being.

\section{[1]}

Perdagangan orang (human trafficking) merupakan fenomena baru di abad moderen, meskipun akar-akarnya telah ada sejak zaman Yunani Kuno dalam bentuk perbudakan. Ia merupakan tindakan kejahatan yang saat ini banyak terjadi di berbagai negara, termasuk di Indonesia. Pemerintah dari setiap negera telah mencoba menghapuskan praktik perdagangan orang, namun hasilnya sangat tidak memuaskan. Banyak orang telah menjadi korban praktik tersebut yang ternyata terus berlangsung hingga saat ini. Tulisan ini mengkaji fenomena perdagangan orang perspektif Hak Asasi Manusia (HAM), Perundang-undangan di Indonesia, dan hukum Islam. Kajian ini menegaskan betapa praktik perdagangan orang merupakan bagian dari kejahatan kemanusiaan yang bertentangan dengan HAM, tata perundangundangan Indonesia, serta melanggar dan bertentangan dengan syariat Islam karena mengebiri hak-hak dasar manusia sebagai makhluk yang merdeka.
\end{abstract}

Keywords: human trafficking; human crime; human right; the philosophy of Islamic law 
Fuad Mustafid

\section{Pendahuluan}

Fenomena perdagangan orang atau human trafficking hingga saat ini masih terus terjadi di mana-mana, termasuk di Indonesia. Banyak orang yang telah menjadi korban dari praktik ini, mulai dari anak-anak, perempuan, hingga orang dewasa. Salah satu sumber menyebutkan bahwa setiap tahun ada sekitar 700 ribu sampai dengan empat juta orang menjadi korban human trafficking (dijual, dibeli, dikirim, dan dipaksa bekerja di luar kemauannya) di seluruh dunia. ${ }^{1}$ Sementara itu, US Departement of State (2010), Lembaga Perserikatan Bangsa-Bangsa, memperkirakan ada sekitar 2,5 juta orang di seluruh dunia yang telah diperjualbelikan dan menjadi korban perdagangan orang. 2

Indonesia belum mempunyai data pasti jumlah korban human trafficking, namun demikian, diperkirakan korbannya mencapai ratusan atau bahkan ribuan orang. Laporan tahunan Departemen Luar Negeri Amerika tentang perdagangan orang tahun 2018 masih memasukkan Indonesia pada lapis kedua dalam memenuhi standar Perlindungan Korban Perdagangan Orang (TPPO). ${ }^{3}$ UNICEF memperkirakan, terdapat 100.000 perempuan dan anak di Indonesia yang diperdagangkan setiap tahunnya untuk eksploitasi seksual komersial, baik di Indonesia sendiri maupun luar negeri. Dari jumlah tersebut, 30 persen di antaranya merupakan perempuan pelacur yang berusia di bawah 18 tahun dan 40.000 hingga 70.000 merupakan anak-anak. ${ }^{4}$

Praktik perdagangan orang ini marak terjadi lantaran dianggap sebagai bisnis yang mampu mendatangkan keuntungan yang sangat besar. ${ }^{5}$ Keuntung-

\footnotetext{
${ }^{1}$ Harkristuti Harkrisnowo, Laporan Perdagangan Manusia di Indonesia (Jakarta: Sentra HAM UI, 2003), 8; Bandingkan dengan Supriyadi Widodo Eddyono, Perdagangan Manusia dalam Rancangan KUHP (Jakarta: ELSAM bekerjasama dengan The Asia Foundation dan USAID, 2005), 2.

${ }^{2}$ Wahyu Riadi, "Implementasi Pencegahan Perdagangan Orang Ditinjau dari Perspektif Pertahanan Negara," Jurnal Strategi Perang Semesta 3, no. 2 (2017): 1-24.

${ }^{3}$ Departemen Luar Negeri AS, "Laporan Departemen Luar Negeri AS mengenai Perdagangan Manusia tahun 2018," https://id.usembassy.gov/id/our-relationship-id/official-reports-id/laporantahunan-perdagangan-orang-2018/.

${ }^{4}$ Lembaga Kajian, Penelitian dan Pengembangan Pengurus Pusat PMKRI St. Thomas Aquinas, “Telaah Human Trafficking di Indonesia," verbivora.com, 2018, http://www.verbivora.com/2018/ 04/telaah-human-trafficking-di-indonesia.html.

${ }^{5}$ Berdasarkan laporan Compas.com, perputaran uang pada perdagangan orang (human trafficking) jauh lebih besar daripada pembalakan liar (illegal loging) maupun perdagangan obat-obatan terlarang, seperti narkotika. Deputi III Bidang Perlindungan Perempuan Kementerian Pemberdayaan
} 
an besar inilah yang mendorong banyak oknum tak bertanggung jawab tergiur untuk terlibat dalam praktik terlarang ini. Persoalan ini sebenarnya telah mendapatkan perhatian serius dari banyak kalangan, baik nasional maupun internasional. Berbagai upaya juga telah dilakukan untuk mencegah terjadinya praktik seperti ini. Secara normatif, aturan-aturan hukum juga telah diciptakan guna mencegah dan mengatasi terjadinya praktik perdagangan orang. Namun demikian, kejahatan kemanusiaan dalam bentuk perdagangan orang ini masih saja berlangsung dan bahkan cenderung meningkat dari tahun ke tahun.

Tulisan ini mengkaji praktik perdagangan orang yang banyak terjadi sekarang ini, khususnya di Indonesia, dari perspektif Hak Asasi Manusia (HAM), peraturan perundang-undangan yang berlaku di Indonesia, dan filsafat hukum Islam. Tulisan ini diawali dengan penjelasan definisi tentang perdagangan orang (human trafficking), faktor-faktor yang turut serta berperan terhadap terjadinya praktik perdagangan orang, modus yang umum digunakan oleh para pelaku perdagangan orang dalam menggaet para korbannya, serta pihak-pihak yang melakukan dan memanfaatkan para korban perdagangan orang tersebut. Penjelasan kemudian dilanjutkan dengan mengkaji dan menganalisis masalah perdagangan orang ini dari perspektif HAM dan filsafat hukum Islam.

\section{Makna dan Karakteristik Perdagangan Orang}

Perdagangan orang berasal dari term trafficking atau human trafficking. Salah satu makna traffic atau trafficking adalah perdagangan. Namun dalam perkembangannya, kata trafficking juga digunakan untuk makna perdagangan orang. Dengan demikian, istilah perdagangan orang merupakan terjemahan dari term human trafficking atau sering juga disingkat dengan trafficking saja. Sedangkan makna trafficking, sebagaimana disebut dalam resolusi Perserikatan Bangsa-Bangsa tahun 1994 yaitu:

... the recruitment, transportation, transfer, harbouring or receipt of persons, by means of the threat or use of force or other forms of coercion, of abduction, of

Perempuan, Subagyo, dalam Seminar Nasional dan Workshop tentang "Penanganan Trafficking dan KDRT dalam Berbagai Perspektif," pernah menyatakan bahwa pada tahun 2008, perputaran uang trafficking mencapai Rp. 32 triliun hingga Rp. 36 triliun. Sementara itu, perputaran uang illegal logging hanya mencapai Rp. 15 triliun dan perdagangan narkotika hanya Rp. 25 triliun" Lihat: Subagyo, "Penanganan Trafficking dan KDRT dalam Berbagai Perspektif," Compas.Com, n.d. 
fraud, of deception, of the abuse of power or of a position of vulnerability or of the giving or receiving of payments or benefits to achieve the consent of a person having control over another person, for the purposes of exploitation. Exploitation shall include, at a minimum, the exploitation of the prostitution of others or other forms of sexual exploitation, forced labour or services, slavery or practices similar to slavery, servitude or the removal of organs...

Sementara dalam Undang-Undang Nomor 21 Tahun 2007 tentang Pemberantasan Tindak Pidana Perdagangan Orang disebutkan bahwa trafficking atau human trafficking adalah:

"Tindakan perekrutan, pengangkutan, penampungan, pengiriman, pemindahan atau penerimaan seseorang dengan ancaman kekerasan, penggunaan kekerasan, penculikan, penyekapan, pemalsuan, penipuan, penyalahgunaan kekuasaan atau posisi rentan, penjeratan utang atau memberi bayaran atau manfaat sehingga memperoleh persetujuan dari orang yang memegang kendali atas orang lain tersebut, baik yang dilakukan di dalam negeri (maupun di luar negeri), untuk tujuan eksploitasi, atau mengakibatkan orang tereksplotasi". ${ }^{7}$

Berdasarkan beberapa definisi di atas, paling tidak ada empat unsur pokok dalam praktik perdagangan orang. Pertama, perbuatan atau tindakan, yaitu tindakan merekrut, mengangkut, menampung, mengirim, memindahkan, atau menerima seseorang yang dilakukan oleh para aktor (traffickers), baik secara langsung ataupun tidak langsung. Kedua, cara atau proses, yaitu cara-cara yang dilakukan oleh traffickers dalam menggaet para korbannya. ${ }^{8}$ Ketiga, migrasi atau perpindahan, yaitu perpindahan orang dari satu daerah ke daerah lain atau dari satu negara ke negara lain, yang dilakukan secara paksa atau dengan disertai ancaman kekerasan. Keempat, tujuan tertentu, yaitu mengeksploitasi atau

${ }^{6}$ GAATW International Secretariat, "Human Rights in Practice: A Guide to Assist Trafficked Women and Children - The Global Alliance Against Traffic in Women (GAATW)," gaatw.org, 1999, 12, https://gaatw.org/home-2/publications/904-human-rights-in-practice-a-guide-to-assist-traffickedwomen-and-children.

7Undang-Undang Nomor 21 Tahun 2007 tentang Pemberantasan Tindak Pidana Perdagangan Orang; Mengenai makna atau pengertian trafficking ini, lihat dan bandingkan juga dengan Andy Yentriyani, Politik Perdagangan Perempuan, ed. Gusmiani Islah (Yogyakarta: Galang Press, 2004). 2122.

${ }^{8}$ Cara-cara yang sering dilakukan dalam praktik trafficking adalah dengan ancaman kekerasan, penggunaan kekerasan, penculikan, penyekapan, pemalsuan, penipuan, penyalahgunaan kekuasaan atau posisi rentan, penjeratan utang, memberi bayaran atau manfaat sehingga memperoleh persetujuan dari orang yang memegang kendali atas orang lain tersebut. Lihat dan bandingkan dengan Eddyono, Perdagangan Manusia dalam Rancangan KUHP, 7-8; Harkrisnowo, Laporan Perdagangan Manusia di Indonesia, 30. 
mengakibatkan seseorang tereksploitasi, baik secara fisik, ekonomi, maupun seksual. Pada umumnya, eksploitasi tersebut dilakukan dalam beberapa bentuk, yaitu prostitusi secara paksa, pembantu rumah tangga, buruh ilegal, adopsi ilegal, pariwisata dan hiburan seks, pornografi dan juga pornoaksi, serta tidak jarang juga dimanfaatkan untuk aktivitas kriminal lainnya. ${ }^{9}$

Selain keempat unsur di atas, terdapat unsur lain yang juga penting untuk diperhatikan yaitu usia seseorang pada saat ia menjadi korban trafficking. Dalam Protokol Palermo ${ }^{10}$ disebutkan bahwa apabila orang yang menjadi korban trafficking masih berada di bawah usia 18 tahun maka unsur-unsur lain dalam praktik tersebut menjadi tidak penting lagi. Sebab, anak yang masih berada di bawah usia 18 tahun dianggap belum memiliki kapasitas untuk memberi atau menerima persetujuan dengan sadar atas tawaran yang diberikan kepadanya. Selain itu, dia juga belum bisa memahami akibat hukum dari persetujuan yang dilakukannya itu.

Terkait dengan migrasi atau pemindahan orang dari satu wilayah ke wilayah lain yang merupakan salah satu unsur praktik trafficking, meliputi tiga daerah berbeda. Pertama, daerah pengirim, yaitu daerah asal para korban. Kedua, daerah transit, yaitu daerah yang menjadi tempat persinggahan sementara para korban sebelum sampai di daerah tujuan. ${ }^{11}$ Ketiga, daerah tujuan, yaitu daerah yang menjadi tujuan para korban. Di Indonesia, daerahdaerah yang menjadi tujuan trafficking pada umumnya adalah kota-kota besar, seperti Jakarta, Surabaya, Bali, Medan, dan Batam. Sementara negara-negara yang menjadi tujuan trafficking, di antaranya yaitu Malaysia, Singapura, Philipina, Thailand, Jepang, Korea Selatan, Hongkong, dan Arab Saudi. ${ }^{12}$ Di

\footnotetext{
${ }^{9}$ Lihat dan bandingkan dengan: Eddyono, Perdagangan Manusia dalam Rancangan KUHP; Salma Safitri Rahayu, "Analisis Rancangan Undang-Undang Pemberantasan Tindak Pidana Perdagangan Orang," Jurnal Perempuan, no. 49 (2006); Harkrisnowo, Laporan Perdagangan Manusia di Indonesia.

${ }_{10}^{10}$ rotokol Palermo adalah peraturan untuk mencegah, menekan dan menghukum perdagangan manusia, khususnya perempuan dan anak, sebagai suplemen Konvensi Perserikatan Bangsa-Bangsa (PBB) untuk melawan organisasi kejahatan lintas bangsa yang digunakan Majelis Umum PBB. (International Labour Organization, 2004). Lihat: Undang-Undang No. 1 Tahun 2000 tentang Pengesahan Konvensi ILO.

${ }^{11}$ Di Indonesia, daerah-daerah yang menjadi transit korban trafficking pada umumnya adalah kota-kota besar, seperti Jakarta, Surabaya, Medan, Batam, Denpasar, Balikpapan, dan Makassar. Akan tetapi, daerah-daerah ini juga tidak jarang menjadi daerah tujuan trafficking. Lihat: Ruth Rosenberg, Perdagangan Perempuan dan Anakdi Indonesia, ed. Ruth Rosenberg (Jakarta: USAID, 2003), 31.

${ }^{12}$ Harkristuti Harkrisnowo, Laporan Perdagangan Manusia di Indonesia, 10.
} 
daerah-daerah atau negara-negara inilah, para korban trafficking biasanya dipekerjakan secara eksploitatif dan tidak manusiawi.

\section{Faktor-Faktor Penyebab Terjadinya Perdagangan Orang}

Secara khusus, tidak diketahui penyebab perdagangan orang. Sedangkan secara umum, ia terjadi lantaran banyak sebab dan kondisi yang berbeda-beda. Namun demikian, Harkristuti Harkrisnowo dalam laporan penelitiannya, menyitir beberapa faktor yang dinilai menjadi pemicu terjadinya praktik trafficking sebagai berikut. ${ }^{13}$ (1) Kecerobohan dari para pencari kerja. Umumnya mereka ingin segera mendapatkan pekerjaan, namun tidak memperhatikan risiko yang akan ditanggungnya, termasuk tidak mengetahui bahaya trafficking dan cara-cara yang digunakan para pelaku untuk menipu atau menggaet para korbannya. ${ }^{14}$ (2) Kemiskinan dan posisi rentan yang mendorong dan memaksa orang untuk mencari kerja ke mana saja tanpa memperhatikan risiko atau bahaya yang ditimbulkan dari pekerjaannya itu. (3) Tuntutan dari keluarga (miskin) agar setiap anggota keluarga bisa bekerja dan menghasilkan uang demi mencukupi biaya kehidupan keluarga. ${ }^{15}$ (4) Kelemahan dokumentasi kelahiran anak, sehingga ada banyak pemalsuan dokumen dan identitas warga negara yang ingin bekerja ke luar negeri. (5) Pengawasan dan perlindungan aparat penegak hukum yang lemah bagi para warganya. ${ }^{16}$

Sementara itu, Kementrian Koordinator Bidang Kesejahteraan Rakyat mencatat bahwa perdagangan orang ini bisa memakan korban siapa saja, lakilaki maupun perempuan, orang dewasa maupun anak-anak. Akan tetapi dalam konteks negara Indonesia, yang menjadi korban trafficking pada umumnya adalah mereka yang berada pada posisi rentan, seperti: (1) berasal dari

\footnotetext{
${ }^{13}$ Harkristuti Harkrisnowo, 67-69.

14Para pencari kerja yang menjadi sasaran empuk perdagangan manusia rata-rata adalah para buruh migran, baik yang datang secara legal maupun ilegal. Bagi yang datang secara legal, mereka menjadi korban karena itikad tidak baik dari biro-biro pengerah tenaga kerja, seperti dengan cara menahan dokumen-dokumen yang diperlukan oleh pekerja pendatang. Mereka sering kali lengah akan kelengkapan dokumen karena keinginan yang sangat besar untuk segera memperoleh pekerjaan. Lihat: Harkrisnowo, 67-9.

15Faktor kemiskinan atau kesulitan ekonomi keluarga inilah yang menjadi salah satu alasan orang tua rela menjual anaknya. Putus sekolah, ketidaktahuan orang tua, serta besarnya harapan orang tua agar anak tidak lagi menjadi tanggungan mereka menjadi faktor lain dari perdagangan manusia.

${ }^{16}$ Harkristuti Harkrisnowo, Laporan Perdagangan Manusia di Indonesia, 69.
} 
keluarga miskin dari pedesaan, ataupun dari kampung-kampung kumuh di perkotaan; (2) berpendidikan dan berpengetahuan rendah (terbatas); (3) terlibat masalah ekonomi, sosial, dan politik yang serius; (4) mengalami krisis ekonomi, (5) keluarga yang kehilangan mata pencaharian, (6) anak-anak putus sekolah, (7) para buruh migran, (8) mendapatkan tekanan dari orang tua atau lingkungan sekitar untuk segera bekerja, ataupun (9) para pekerja seks yang menganggap bahwa bekerja di luar negeri akan menghasilkan kekayaan yang lebih banyak. ${ }^{17}$

Semua korban trafficking ini dipekerjakan secara eksploitatif, sehingga sangat merugikan para korban. Ada banyak bentuk eksploitasi yang umum dilakukan oleh traffickers, di antaranya yaitu prostitusi secara paksa, pembantu rumah tangga -inilah pekerjaan yang paling umum diterima oleh para korban trafficking- yang tidak menerima imbalan sebagaimana mestinya, pelayan hotel, baby sitter, buruh ilegal, adopsi ilegal, pariwisata dan hiburan seks, pornografi dan pornoaksi, serta aktivitas kriminal lainnya. ${ }^{18}$

\section{Modus Traffickers dalam Menggaet Para Korbannya}

Kementerian Bidang Kesejahteraan Sosial menyebutkan beberapa modus yang umum digunakan oleh para traffickers dalam menggaet para korbannya. Di antaranya dengan membujuk atau merayu calon korban, yaitu dengan menjanjikan berbagai kesenangan dan kemewahan, menipu atau janji palsu, menjebak, mengancam, menyalahgunakan wewenang, menjerat dengan hutang, mengawini, menculik, menyekap atau memperkosa, dan cara-cara lain yang bisa mendorong calon korban mengikuti kemauan para traffickers. ${ }^{19}$

Modus lainnya dilakukan dengan berkedok mencari tenaga kerja untuk bisnis entertainment, kerja di perkebunan, atau bidang jasa di luar negeri dengan upah besar. Ibu-ibu hamil yang kesulitan biaya untuk melahirkan atau mem-

\footnotetext{
17Parjoko, Maswita Djaja, dan Soetedjo Yuwono, Penghapusan Perdagangan Orang (Trafficking in Persons) di Indonesia (Kementerian Koordinantor Bidang Kesejahteraan Rakyat, 2005), 4.

18Wahyu Tini Astuti, "Perdagangan Perempuan untuk Tujuan Pelacuran: Studi Kasus tentang Perempuan Penjual Minuman di Sepanjang Rel Kereta Api di Jakarta” (Tesis, Universitas Indonesia, 2008); Harkrisnowo, Laporan Perdagangan Manusia di Indonesia; Rina Antasari RR, "Penanganan Tindak Pidana Perdagangan Orang dalam Perspektif Global dan Islam di Sumatra Selatan," Jurnal Intizar 24, no. 1 (2018): 115-40, https://doi.org/10.19109/intizar.v24i1.2184.

${ }^{19}$ Parjoko, Djaja, dan Yuwono, Penghapusan Perdagangan Orang (Trafficking in Persons) di Indonesia., 4
} 
besarkan anak dibujuk dengan jeratan utang supaya anaknya boleh diadopsi agar dapat hidup lebih baik, namun kemudian dijual kepada orang yang menginginkan. Anak-anak di bawah umur dibujuk agar bersedia melayani para pedofil dengan memberikan barang-barang keperluan mereka dan bahkan janji untuk disekolahkan.20

Para trafficker yang hendak menyalurkan para korbannya ke luar negeri, dalam melakukan aksinya tidak jarang bekerja sama dengan pengurus RT/RW, kelurahan, dan kecamatan dalam proses pemalsuan KTP atau Akte Kelahiran. Hal itu dilakukan karena adanya syarat umur tertentu yang dituntut oleh agen untuk pengurusan dokumen (paspor). Dalam pemrosesannya, juga sering melibatkan dinas-dinas yang tidak cermat meneliti kesesuaian identitas dengan subjeknya. ${ }^{21}$

Pada umumnya, agen dan calo perdagangan orang mendekati korbannya di rumah-rumah pedesaan, di keramaian pesta-pesta pantai, mall, kafe atau di restoran. Para agen atau calo ini bekerja dalam kelompok dan sering kali menyamar sebagai remaja yang sedang bersenang-senang atau sebagai agen pencari tenaga kerja. Jika ada korban yang berhasil direkrut maka akan segera dibawa ke tempat transit atau bisa juga langsung ke tempat tujuan. ${ }^{22}$

Para korban, setelah sampai di tempat tujuan, tinggal di rumah penampungan selama beberapa minggu untuk menunggu penempatan kerja yang dijanjikan. Akan tetapi dalam kenyataannya, mereka dibawa ke bar, pub, salon kecantikan, rumah bordil dan rumah hiburan lain, dan mulai dilibatkan dalam kegiatan prostitusi. Mereka diminta menandatangani kontrak yang tidak mereka mengerti isinya. Jika menolak, korban diminta membayar kembali biaya perjalanan dan tebusan dari agen atau calo yang membawanya. Jumlah yang biasanya membengkak itu kemudian menjadi hutang yang harus ditanggung oleh korban.23 Inilah yang menjadi salah satu penyebab para korban susah untuk melepaskan diri dari jeratan pelaku trafficking.

\footnotetext{
20Parjoko, Djaja, dan Yuwono.

21Parjoko, Djaja, dan Yuwono.

${ }^{22}$ Biasanya, agen atau calo akan menyertai mereka dan menanggung biaya perjalanan. Untuk ke luar negeri, mereka dilengkapi dengan visa turis, tetapi seluruh dokumen dipegang oleh agen, termasuk dalam penanganan masalah keuangan. Sering kali perjalanan dibuat memutar untuk memberi kesan bahwa perjalanan yang ditempuh sangat jauh sehingga sulit untuk kembali. Bila muncul keinginan korban untuk kembali pulang, mereka ditakut-takuti atau diancam. Lihat: Parjoko, Djaja, dan Yuwono.
}

23Parjoko, Djaja, dan Yuwono. 


\section{Pelaku dan Pengguna Korban Trafficking}

Para pelaku perdagangan orang ini sudah pasti mereka yang telah kehilangan naluri kemanusiaannya dan memiliki hasrat tinggi untuk mendapatkan kekayaan dengan menempuh cara yang melanggar aturan. Dalam melakukan aksinya, para pelaku perdagangan orang ini biasanya melibatkan lembaga, perorangan, tokoh masyarakat, dan bahkan kerabat dekatnya sendiri yang sering kali tidak mereka sadari. ${ }^{24}$ Selain itu, praktik perdagangan orang ini juga sering melibatkan organisasi kejahatan internasional yang melintasi batas-batas wilayah ataupun negara. 25

Pemerintan Indonesia, melalui Kementerian Koordinator Bidang Kesejahteraan Rakyat memberikan penjelasan cukup detil tentang organisasi atau individu yang biasa berperan sebagai pelaku human trafficking ini. ${ }^{26}$ Mereka yaitu (a) Perusahaan perekrut tenaga kerja dengan jaringan agen atau calo di daerah,, ${ }^{27}$ (b) agen atau calo,, ${ }^{28}$ (c) aparat pemerintah, ${ }^{29}$ (d) majikan, ${ }^{30}$ (e) pemilik atau pengelola rumah bordil, ${ }^{31}$ (f) calo pernikahan, ${ }^{32}$ (g) orang tua

\footnotetext{
24Parjoko, Djaja, dan Yuwono, 7.

25Parjoko, Djaja, dan Yuwono.

26Parjoko, Djaja, dan Yuwono.
}

${ }^{27}$ Perusahaan perekrut tenaga kerja bisa disebut sebagai pelaku perdagangan perempuan manakala mereka memfasilitasi pemalsuan KTP dan paspor serta secara ilegal menyekap calon pekerja migran di penampungan, dan menempatkan mereka dalam pekerjaan yang berbeda atau secara paksa memasukkannya ke industri seks.

${ }^{28} \mathrm{Agen}$ atau calo ini bisa berasal dari orang luar, tetapi bisa juga seorang tetangga, teman, atau bahkan kepala desa, yang dianggap trafficker (pelaku perdagangan perempuan) manakala dalam perekrutan tenaga kerja mereka menggunakan kebohongan, penipuan, atau pemalsuan dokumen.

${ }^{29}$ Aparat pemerintah bisa dianggap sebagai traffickers (pelaku perdagangan orang) manakala terlibat dalam pemalsuan dokumen, membiarkan terjadinya pelanggaran dan memfasilitasi penyeberangan melintasi perbatasan secara ilegal.

30Majikan adalah trafficker manakala menempatkan pekerjanya dalam kondisi eksploitatif, seperti tidak membayar gaji, menyekap pekerja, melakukan kekerasan fisik atau seksual, memaksa untuk terus bekerja, atau menjerat pekerja dalam lilitan utang.

31Pemilik atau pengelola rumah bordil dapat dianggap melanggar hukum, terlebih jika mereka memaksa perempuan bekerja di luar kemauannya, menjeratnya dalam libatan utang, menyekap dan membatasi kebebasannya bergerak, tidak membayar gajinya, atau merekrut dan mempekerjakan anak (di bawah 18 tahun).

${ }^{32}$ Calo pernikahan adalah trafficker manakala pernikahan yang diaturnya telah mengakibatkan pihak isteri terjerumus dalam kondisi serupa perbudakan dan eksploitatif walaupun mungkin calo yang bersangkutan tidak menyadari sifat eksploitatif pernikahan yang akan dilangsungkan. 
dan sanak saudara, ${ }^{33}$ dan bahkan juga (h) suami. ${ }^{34}$ Mereka inilah yang berusaha mengambil keuntungan dari praktik perdagangan orang.

Mengacu pada terminologi yang ada dalam hukum pidana, mereka dapat digolongkan ke dalam pihak-pihak yang terlibat dalam praktik kejahatan sebagaimana diatur dalam Pasal 55 dan Pasal 56 KUHP. Dalam Pasal 55 KUHP disebutkan bahwa pelaku kejahatan melingkupi pelaku itu sendiri, pembujuk, atau orang yang menyuruh dengan tekanan atau paksaan. Dengan demikian, pihak-pihak yang terlibat dalam praktik perdagangan orang dapat digolongkan dalam pihak yang mengambil keuntungan dari perdagangan manusia (the person who achieve the concent of person having control over another person) serta orang yang dibayar atau memperoleh keuntungan (person who has been giving or recieving of payment or benefits)..$^{35}$ Sementara bentuk lain dari pelaku kejahatan sebagaimana diatur dalam Pasal 56 KUHP, yaitu orang yang membantu dengan cara menyediakan sarana, prasarana atau keterangan yang dalam banyak kasus justru dilakukan oleh penyedia jasa angkutan, masyarakat, polisi dan Pemda. ${ }^{36}$

Adapun para pengguna perdagangan perempuan, baik yang secara langsung mengambil keuntungan dari para korban, maupun yang tidak secara langsung melakukan eksploitasi, adalah: (a) para germo dan pengelola rumah

\footnotetext{
${ }^{33}$ Orang tua adalah trafficker manakala mereka secara sadar menjual anak atau saudaranya baik langsung atau melalui calo kepada majikan di sektor industri seks atau lainnya. Atau jika mereka menerima pembayaran di muka untuk penghasilan yang akan diterima oleh anak mereka nantinya. Demikian pula jika orang tua menawarkan layanan dari anak mereka guna melunasi utangnya dan menjerat anaknya dalam libatan utang.

${ }^{34}$ Suami adalah trafficker manakala ia menikahi perempuan tetapi kemudian mengirim isterinya ke tempat lain untuk mengeksploitirnya demi keuntungan ekonomi, menempatkannya dalam status budak, atau memaksanya melakukan prostitusi.

35 Lihat Kitab Undang-Undang Hukum Pidana (KUHP) Pasal 55. Para pelaku perdagangan orang ini biasanya menggunakan berbagai cara yang bisa menarik calon korbannya, seperti dengan menjanjikan berbagai kesenangan dan kemewahan, menipu atau janji palsu, menjebak, mengancam, menyalahgunakan wewenang, menjerat dengan hutang, mengawini, menculik, menyekap, atau memperkosa, dan cara-cara lain yang bisa mendorong calon korban mengikuti kemauan para traffickers. Lihat: Parjoko, Djaja, dan Yuwono, Penghapusan Perdagangan Orang (Trafficking in Persons) di Indonesia, 7.

36Kitab Undang-Undang Hukum Pidana (KUHP), Pasal 56. Khusus untuk Polisi dan Pemda, bantuan yang dimaksud adalah bantuan yang dilakukan baik secara aktif maupun secara pasif. Secara aktif dilakukan dengan membantu korban membuak KTP palsu dengan memalsukan identitas antara lain umur bagi anak-anak. Sementara bantuan secara pasif adalah dengan cara tidak melakukan sesuatu hal untuk mencegah terjadinya perdagangan manusia.
} 
bordil yang membutuhkan perempuan dan anak-anak untuk dipekerjakan sebagai pelacur; (b) laki-laki hidung belang, pengidap pedofilia dan kelainan seks lainnya, serta para pekerja asing (eks-patriat) dan pebisnis internasional yang tinggal untuk sementara waktu di suatu negara; (c) para pengusaha yang membutuhkan pekerja anak yang murah, penurut, mudah diatur dan mudah ditakut-takuti; (d) pengusaha bisnis hiburan yang memerlukan perempuan muda untuk dipekerjakan di panti pijat, karaoke, dan tempat-tempat hiburan lainnya; (e) para pebisnis di bidang pariwisata yang juga menawarkan jasa layanan wisata seks; (f) agen penyalur tenaga kerja yang tidak bertanggung jawab; (g) sindikat narkoba yang memerlukan pengedar baru untuk memperluas jaringannya, dan (h) keluarga menengah dan atas yang membutuhkan perempuan dan anak untuk dipekerjakan sebagai pembantu rumah tangga. ${ }^{37}$ Baik pelaku maupun pengguna korban perdagangan perempuan ini, sungguh tidak manusiawi karena telah mengeksploitasi para korbannya demi kepentingan dan keuntungan mereka sendiri.

Mencermati paparan di atas, human trafficking dapat dikatakan merupakan fenomena khas abad modern, meskipun akar-akarnya telah ada sejak zaman Yunani dalam bentuk perbudakan. Dengan demikian, ia sebenarnya merupakan bentuk baru dari perbudakan atau dengan kata lain, perdagangan orang merupakan wujud nyata dari perbudakan di abad modern.

\section{Indonesia sebagai Negara Asal dan Tujuan Perdagangan Orang}

Seperti telah disebutkan di depan bahwa perdagangan orang terjadi di banyak negara dan ia melintasi batas-batas wilayah dan negara. Indonesia menjadi salah satu dari sekian banyak negara yang menghadapi persoalan yang sama. Laporan Kedutaan Besar dan Konsulat AS di Indonesia menyatakan bahwa Indonesia merupakan salah satu negara asal utama, dan pada tataran tertentu, juga menjadi negara tujuan serta transit bagi para pekerja paksa dan korban perdagangan seks. ${ }^{38}$ Banyak orang, baik laki-laki maupun perempuan serta orang dewasa maupun anak-anak Indonesia, yang dikirim ke Malaysia, Singapura, Brunei, Taiwan, Jepang, Hongkong, dan Timur Tengah. Di

\footnotetext{
37Parjoko, Djaja, dan Yuwono, Penghapusan Perdagangan Orang (Trafficking in Persons) di Indonesia, 8.

38Departemen Luar Negeri AS, “Laporan Departemen Luar Negeri AS mengenai Perdagangan Manusia tahun 2018."
} 
sisi lain, Indonesia juga menjadi negara tujuan perdagangan orang yang berasal dari China, Thailand, Hongkong, Uzbekistan, Belanda, Polandia, Venezuela, Spanyol, dan Ukraina. ${ }^{39}$

Kedutaan Besar dan Konsulat AS di Indonesia juga melaporkan bahwa di negara-negara tujuan, banyak warga Indonesia yang dieksploitasi menjadi pekerja paksa, terutama di sektor pekerja rumah tangga, pelayan hotel, buruh pabrik, pekerja konstruksi, pekerja manufaktur, perkebunan kelapa sawit di Malaysia, dan kapal-kapal penangkap ikan yang beroperasi di Samudera Hindia dan Samudra Pasifik. ${ }^{40}$ Kalangan perempuan, baik dewasa maupun remaja, menjadi sasaran perdagangan seks, terutama di Malaysia, Taiwan, dan Timur Tengah. ${ }^{41}$ Sementara di dalam negeri, para korban trafficking dieksploitasi di bidang penangkapan ikan, pengolahan ikan, konstruksi, perkebunan (kelapa sawit), serta pertambangan dan manufaktur. Selain itu, banyak juga kalangan peremupuan yang dieksploitasi di sektor rumah tangga dan perdagangan seks. Mereka sering kali direkrut dengan iming-iming penawaran kerja di restoran, pabrik, atau menjadi asisten rumah tangga tetapi kemudian dipekerjakan sebagai pekerja seks komersial (PSK).42

Data UNICEF memperkirakan bahwa terdapat 100.000 perempuan dan anak di Indonesia diperdagangkan setiap tahunnya untuk eksploitasi seksual komersial di Indonesia sendiri maupun luar negeri. Dari jumlah tersebut, 30 persen di antaranya merupakan perempuan yang berusia di bawah 18 tahun

\footnotetext{
39Lembaga Kajian Penelitian dan Pengembangan Pengurus Pusat PMKRI St. Thomas Aquinas, “Telaah Human Trafficking di Indonesia”; Harkrisnowo, Laporan Perdagangan Manusia di Indonesia, 8.

${ }^{40}$ Nelayan Indonesia yang bekerja di kapal berbendera asing melaporkan perlakuan buruk yang berkepanjangan, praktik kerja paksa, gaji yang tidak dibayar, dan, dalam beberapa kasus terdapat dugaan pembunuhan. Mereka bekerja di kapal penangkap ikan berbendera Taiwan, Thailand, Malaysia, dan Filipina yang beroperasi di Indonesia dan perairan Thailand, Sri Lanka, Mauritius, dan India. Banyak agen perekrutan di Myanmar, Indonesia, dan Thailand mempekerjakan nelayan dengan memberi mereka identitas dan surat izin kerja palsu, memaksa mereka untuk mencari ikan di tengah laut dengan jam kerja yang penjang dan merenima gaji rendah atau tidak dibayar sama sekali serta kerap menerima siksaan fisik. Para nelayan tersebut dilarang meninggalkan kapal dan melaporkan penyiksaan tersebut di bawah ancaman pengaduan kepada otoritas setempat atas kepemilikan identitas palsu atau ditahan di penjara sementara di darat. Terdapat lebih dari 7.000 nelayan Indonesia yang masuk dan keluar bekerja di kapal-kapal asing yang berlabuh di Cape Town, Afrika Selatan, dan dilaporkan menghadapi kondisi kerja yang buruk, terutama bagi mereka yang bekerja di kapal-kapal Taiwan, Korea, dan Jepang. Lihat: Departemen Luar Negeri AS, "Laporan Departemen Luar Negeri AS mengenai Perdagangan Manusia tahun 2018."

${ }^{41}$ Departemen Luar Negeri AS.

${ }^{42}$ Departemen Luar Negeri AS.
} 
dan 40.000 hingga 70.000 merupakan anak-anak. ${ }^{43}$ Sementara Laporan International Organization for Migration (IOM) menyebutkan, jumlah korban perdagangan orang di Indonesia antara tahun 2005-2017 mencapai 8876 orang dan mayoritas merupakan kaum perempuan dan anak-anak di bawah umur. ${ }^{44}$

Para korban perdagangan perempuan berasal dari berbagai wilayah di Indonesia. Para korban berasal dari daerah yang kondisi ekonominya kurang baik atau daerah-daerah di mana tingkat pendidikan dan pengetahuan masyarakat masih rendah. Hal ini selaras dengan karakteristik korban yang umumnya kurang atau tidak berpendidikan dan berasal dari keluarga yang secara ekonomi kurang baik. Laporan Kedutaan Besar dan Konsulat AS di Indonesia menyebutkan bahwa seluruh provinsi (34 provinsi) di Indonesia merupakan daerah asal sekaligus tujuan perdagangan orang. ${ }^{45}$ Namun demikian, Harkristuti Harkrisnowo dalam laporan penelitiannya menyebutkan beberapa wilayah yang menjadi "lahan basah" perdagangan orang, yaitu (1) Jawa Barat (Sukabumi, Tangerang, Bekasi, Indramayu, Karawang, Cianjur, Ciroyom, Cirebon, dan Kuningan) (2) Jawa Tengah (Banyumas, Magelang, Semarang, Tegal, Pekalongan, Purwodadi, Grobogan, Jepara, dan Boyolali) (3) Jawa Timur (Banyuwangi, Nganjuk, Madiun, Kediri, Blitar, Jember, Gresik) (4) Sumatera (Medan, Bitung, Palembang, Lampung, Batam, dan Riau) (5) Kalimantan (Pontianak, Samarinda, dan Landak) (6) Sulawesi (Manado, Sengkang, dan Watampone), dan (7) Nusa Tenggara Timur.46 Pada tahun 2015, daerah Jawa Barat menempati posisi teratas sebagai daerah asal dan korban perdagangan orang, dengan jumlah korban mencapai 2151 orang, kemudian Jawa Tengah dengan jumlah 909 orang, dan Kalimantan dengan jumlah 732 orang.47 Sementara pada tahun 2017, terdapat lima daerah yang dikategorikan sebagai

\footnotetext{
43Lembaga Kajian Penelitian dan Pengembangan Pengurus Pusat PMKRI St. Thomas Aquinas, "Telaah Human Trafficking di Indonesia."

${ }^{44}$ Andy Ardian, "KPAI: Diskusi Pemetaan Daerah Rawan, Pencegahan dan Penanganan Trafficking dan Eksploitasi Anak di Indonesia," ECPAT Indonesia, 2017, https://ecpatindonesia.org/berita/kpaidiskusi-pemetaan-daerah-rawan-pencegahan-dan-penanganan-trafficking-dan-eksploitasi-anak-diindonesia/.

${ }^{45}$ Ardian.

46Harkrisnowo, Laporan Perdagangan Manusia di Indonesia, 85; Lembaga Kajian Penelitian dan Pengembangan Pengurus Pusat PMKRI St. Thomas Aquinas, "Telaah Human Trafficking di Indonesia."

${ }^{47}$ Lembaga Kajian Penelitian dan Pengembangan Pengurus Pusat PMKRI St. Thomas Aquinas, "Telaah Human Trafficking di Indonesia."
} 
lahan basah dan sekaligus masuk zona merah perdagangan orang. Kelima daerah tersebut yaitu (1) Nusa Tenggara Timur (NTT), (2) Nusa Tenggara Barat (NTB), (3) Jawa Timur, (4) Jawa Tengah, dan (5) Jawa Barat. Pada akhir tahun 2017, NTT menempati posisi atas sebagai daerah yang mengalami perdagangan orang 48

\section{Perdagangan Orang dalam Perspektif Hak Asasi Manusia}

Setiap manusia pada dasarnya bebas dan merdeka. Ia memiliki posisi yang sama di depan hukum (equality before the law) karena pada hakikatnya manusia itu sama dan sederajat. Undang-Undang Hak Asasi Manusia (Bill of Rights) yang dicetuskan di Inggris pada 1689 menyatakan bahwa asas persamaan antar manusia harus diwujudkan betapa pun berat rintangan yang dihadapi. Hal ini disebabkan, tanpa hak persamaan, hak kebebasan manusia mustahil dapat terwujud. ${ }^{49}$

Terkait dengan hak-hak dasar manusia, John Lock mencetuskan teori hukum kodrati yang menyatakan bahwa di dalam masyarakat manusia terdapat hak-hak dasar manusia yang tidak dapat dilanggar oleh negara dan juga tidak diserahkan kepada negara. Bagi John Lock, hak dasar manusia ini justru harus dilindungi oleh negara dan menjadi batasan bagi kekuasaan negara yang mutlak. Hak-hak kodrati (alamiah) manusia yang dicetuskan John Lock meliputi (1) hak atas kehidupan, (2) hak atas kemerdekaan, dan (3) hak atas milik pribadi..$^{50}$ Masih menurut John Lock, hak asasi manusia tersebut merupakan hak-hak yang diberikan langsung oleh Tuhan sebagai sesuatu yang bersifat kodrati. Oleh karenanya, tidak ada seorang pun atau kekuasaan mana pun di dunia yang berhak mencabutnya. ${ }^{51}$ Jan Materson dari komisi HAM PBB, sebagaimana dikutip oleh Baharuddin Lopa, juga menyatakan nilai penting dari hak asasi manusia. Menurutnya, hak asasi manusia adalah hak-hak yang melekat pada manusia yang tanpanya, manusia mustahil dapat hidup sebagai manusia. $^{52}$

\footnotetext{
48Lembaga Kajian Penelitian dan Pengembangan Pengurus Pusat PMKRI St. Thomas Aquinas.

${ }^{49}$ A. Ubaedillah dan Abdul Rozak, Demokrasi dan Hak Asasi Manusia, dan Masyarakat Madani, Edisi Revisi (Jakarta: ICCE UIN Syarif Hidayatullah bekerjasama dengan the Asia Foundation, 2006), 253.

50Ubaedillah dan Rozak, 253-4.

51Ubaedillah dan Rozak, 252.

52Tim ICCE UIN Jakarta, Demokrasi, Hak Asasi Manusia, dan Mayarakat Madani (Jakarta: Kencana, 2003), 200.
} 
Sementara itu, di dalam Pasal 1 Undang-Undang No. 39 Tahun 1999 tentang Hak Asasi Manusia, dinyatakan bahwa hak asasi manusia (HAM) adalah seperangkat hak yang melekat pada hakikat dan keberadaan manusia sebagai makhluk Tuhan Yang Maha Esa dan merupakan anugerah-Nya yang wajib dihormati, dijunjung tinggi, dan dilindungi oleh negara, hukum, pemerintah, dan setiap orang, demi kehormatan serta perlindungan harkat dan martabat manusia. ${ }^{53}$ Dengan demikian, ia merupakan hak dasar setiap manusia yang dibawa sejak lahir dan merupakan anugerah Tuhan Yang Maha Pencipta, bukan pemberian manusia ataupun lembaga kekuasaan.

Mengingat begitu penting jaminan perlindungan terhadap hak dasar manusia dan banyak kasus pelanggaran terhadapnya, masyarakat dunia kemudian memandang perlu merumuskan sebuah konsep atau aturan yang bisa menjamin hak-hak tersebut. Rumusan itulah yang kemudian melahirkan Deklarasi Universal Hak Asasi Manusia (DUHAM) yang kemudian dikukuhkan oleh PBB dalam Universal Declaration of Human Right (UDHR) pada tahun 1948. Menurut DUHAM, terdapat 5 jenis hak asasi yang dimiliki oleh setiap manusia, yaitu (1) hak personal (hak jaminan kebutuhan pribadi), (2) hak legal (hak jaminan perlindungan hukum), (3) hak sipil dan politik, (4) hak subsistensi (hak jaminan adanya sumber daya untuk menunjang kehidupan, dan (5) hak ekonomi, sosial, dan budaya. ${ }^{44}$ Pasal-pasal di dalam DUHAM juga menyatakan secara jelas tentang hak-hak dasar manusia, yaitu (1) hak untuk hidup, kebebasan dan keamanan pribadi, (2) hak bebas dari perbudakan dan penghambaan, (3) hak bebas dari penyiksaan atau hukuman yang kejam, tak berperikemanusiaan ataupun merendahkan derajat kemanusiaan, dan (4) hak bebas dari penangkapan, penahanan, atau pembuangan yang sewenangwenang. ${ }^{55}$ Mencermati isi dan ketentuan yang ada di dalam DUHAM maka perdagangan orang (human trafficking) merupakan tindakan yang nyata-nyata melanggar hak asasi manusia dan kejahatan terhadap kemanusiaan. ${ }^{56}$

\footnotetext{
53“Undang-Undang No. 39 Tahun 1999 tentang Hak Asasi Manusia".

54Tim ICCE UIN Jakarta, Demokrasi, Hak Asasi Manusia, dan Mayarakat Madani, 255.

55Tim ICCE UIN Jakarta.

56Pasal 9 Undang-Undang Nomor 26 Tahun 2000 Tentang Pengadilan Hak Asasi Manusia menyatakan bahwa kejahatan kemanusiaan adalah salah satu perbuatan yang dilakukan sebagai bagian dari serangan yang meluas atau sistematik yang diketahui bahwa serangan tersebut ditujukan secara langsung terhadap penduduk sipil, di antaranya berupa: (a) perbudakan, (b) pengusiran atau pemindahan penduduk secara paksa; (c) perampasan kemerdekaan atau perampasan kebebasan
} 


\section{Perdagangan Orang dalam Ketentuan Perundangan-Undangan di Indonesia}

Indonesia, sebagai negara yang menjunjung tinggi nilai-nilai kemanusiaan, mengecam segala bentuk pelecehan terhadap hak asasi manusia. Hal tersebut dapat dilihat di dalam berbagai peraturan perundang-undangan Indonesia, seperti Undang-Undang No. 39 Tahun 1999 tentang Hak Asasi Manusia, Undang-Undang No. 1 Tahun 2000 tentang Pengesahan Konvensi ILO, Undang-Undang No. 26 Tahun 2000 tentang Pengadilan Hak Asasi Manusia, dan Undang-Undang No. 23 Tahun 2002 tentang Perlindungan Anak.

Undang-Undang No. 39 Tahun 1999 tentang Hak Asasi Manusia yang merupakan payung bagi perlindungan HAM setiap orang yang berada di Indonesia, memberikan sejumlah asas yang penting bagi kebebasan dan perlindungan terhadapnya, termasuk perlindungan terhadap perdagangan orang (human trafficking). Asas-asas tersebut, di antaranya: ${ }^{77}$ Pertama, Pasal 3 UU No. 39 Tahun 1999 menyatakan bahwa "setiap orang dilahirkan bebas dengan harkat dan martabat manusia yang sama dan sederajat serta dikaruniai akal dan hati nurani untuk hidup bermasyarakat, berbangsa dan bernegara, dalam semangat persaudaraan" (Ayat 1) dan bahwa "setiap orang berhak atas perlindungan hak asasi manusia dan kebebasan dasar manusia" (Ayat 3). Kedua, Pasal 4 UU No. 39 Tahun 1999 menyatakan bahwa hak untuk hidup, hak untuk tidak disiksa, hak kebebasan pribadi, pikiran dan hati nurani, hak beragama, hak untuk tidak diperbudak, hak untuk diakui sebagai pribadi dan persamaan di hadapan hukum, dan hak untuk tidak dituntut atas dasar hukum yang berlaku surut merupakan hak asasi manusia yang tidak dapat dikurangi dalam keadaan apa pun dan oleh siapa pun. ${ }^{58}$ Ketiga, Pasal 20 UU No. 39 Tahun 1999 menyatakan bahwa "tidak seorang pun boleh diperbudak atau diperhamba" (Ayat 1). Oleh karena itu, "perbudakan atau perhambaan,

secara fisik lain secara sewenang-wenang yang melanggar (asas-asas) ketentuan hukum internasional, dan (d) perbudakan seksual, pelacuran secara paksa, pemaksaan kehamilan. Lihat: "Undang-Undang No. 26 Tahun 2000 tentang Pengadilan Hak Asasi Manusia".

57Undang-Undang No. 39 Tahun 1999 Tentang Hak Asasi Manusia.

58Dalam penjelasan atas Undang-Undang No. 39 Tahun 1999 tentang Hak Asasi Manusia, dinyatakan bahwa "Yang dimaksud dengan "dalam keadaan apa pun", termasuk dalam keadaan perang, sengketa bersenjata, dan atau keadaan darurat. Sementara yang dimaksud dengan "siapa pun" adalah Negara pemerintah dan atau anggota masyarakat. Lihat Penjelasan atas Pasal 4 UndangUndang No. 39 Tahun 1999 tentang Hak Asasi Manusia. 
perdagangan budak, perdagangan wanita, dan segala perbuatan berupa apa pun yang tujuannya serupa adalah dilarang (Ayat 2).

Segala tindakan yang membatasi kebebasan manusia, merendahkan martabat manusia, mengeksploitasi, memperbudak, memperdagangkan manusia, dan segala perbuatan yang tujuannya serupa, dengan demikian bertentangan dengan HAM dan peraturan perundang-undangan yang ada. Ketentuan ini berlaku bagi semua manusia, baik dewasa maupun anak-anak. Bahkan, di dalam undang-undang ini, anak-anak yang sering menjadi korban trafficking mendapatkan perhatian serius. Pasal 65 UU No. 39 Tahun 1999 ini menyatakan bahwa "setiap anak berhak untuk memperoleh perlindungan dari kegiatan eksploitasi dan pelecehan seksual, penculikan, perdagangan anak, serta dari berbagai bentuk penyalahgunaan narkotika, psikotropika, dan zat adiktif lainnya. ${ }^{59}$

UU No. 1 Tahun 2000 tentang Pengesahan Konvensi ILO juga memberikan perhatian serius terhadap nasib anak-anak yang sering menjadi korban trafficking. Dalam undang-undang tersebut dinyatakan secara jelas tentang perlindungan terhadap anak dari segala bentuk eksploitasi, termasuk pekerjaan-pekerjaan yang dianggap tidak layak (buruk) bagi mereka. Bahkan undang-undang ini memerintahkan untuk segera menghapus segala bentuk pekerjaan terburuk untuk anak. ${ }^{60}$

Pasal 3 UU No. 1 Tahun 2000 tentang Pengesahan Konvensi ILO menyatakan bahwa batas usia minimum anak untuk diperbolehkan bekerja di setiap jenis pekerjaan, yang karena sifat atau keadaan lingkungan tempat pekerjaan itu dilakukan dapat membahayakan kesehatan, keselamatan, atau moral orang muda, tidak boleh kurang dari 18 tahun. ${ }^{61}$ Adapun pekerjaan-pekerjaan terburuk untuk anak menurut undang-undang ini yaitu: (1) segala bentuk perbudakan atau praktik-praktik sejenis perbudakan, seperti penjualan dan perdagangan anak-anak, kerja ijon (debit bondage) dan perhambaan serta

\footnotetext{
59Undang-Undang No. 39 Tahun 1999 tentang Hak Asasi Manusia.

${ }^{60} \mathrm{Hal}$ senada juga tertuang dalam Undang-Undang No. 1 Tahun 2000 tentang Pengesahan Konvensi ILO No. 138 mengenai usia minimum untuk diperbolehkan bekerja.

61 Undang-Undang No. 1 Tahun 2000 tentang Pengesahan Konvensi ILO; penjelasan tentang batas umur seseorang yang masih dianggap sebagai anak juga bisa ditemukan dalam Undang-Undang No. 23 Tahun 2002. Dalam Pasal 1 Ayat 1 undang-undang ini dijelaskan bahwa yang dimaksud dengan anakadalah seseorang yang belum berusia 18 tahun, termasukanak yang masih dalam kandungan.
} 
kerja paksa atau wajib kerja, termasuk pengerahan anak-anak secara paksa atau wajib kerja; (2) pemanfaatan, penyediaan, atau penawaran anak untuk pelacuran, produksi pornografi, atau pertunjukan-pertunjukan porno; (3) pemanfaatan, penyediaan atau penawaran anak untuk kegiatan haram, khususnya untuk produksi dan perdagangan obat-obatan sebagaimana diatur dalam perjanjian internasional yang relevan; dan (4) pekerjaan yang sifatnya atau lingkungan tempat pekerjaan itu dilakukan dapat membahayakan kesehatan, keselamatan, atau moral anak.

Untuk menghindari dan mencegah terjadinya eksploitasi anak, UU No. 23 Tahun 2002 tentang Perlindungan Anak menyatakan bahwa anak-anak harus dijamin dan dilindungi hak-haknya agar dapat hidup, tumbuh, berkembang, dan berpartisipasi, secara optimal sesuai dengan harkat dan martabat kemanusiaan, serta mendapat perlindungan dari kekerasan dan diskriminasi. Perlindungan tersebut merupakan perlindungan dari perlakuan: (a) diskriminasi; (b) eksploitasi, baik ekonomi maupun seksual; (c) penelantaran; (d) kekejaman, kekerasan, dan penganiayaan; (e) ketidakadilan; dan (f) perlakuan salah lainnya, misalnya tindakan pelecehan atau perbuatan tidak senonoh kepada anak (Pasal 1 Ayat 2). Dalam hal ini, pemerintah dan lembaga-lembaga negara bertanggung jawab atas jaminan keamanan anak. Hal ini dinyatakan secara jelas dalam Pasal 59 UU Perlindungan Anak. Dalam pasal tersebut dinyatakan:

Pemerintah dan lembaga negara lainnya berkewajiban dan bertanggung jawab untuk memberikan perlindungan khusus kepada anak dalam situasi darurat, anak yang berhadapan dengan hukum, anak dari kelompok minoritas dan terisolasi, anak tereksploitasi secara ekonomi dan/atau seksual, anak yang diperdagangkan, anak yang menjadi korban penyalahgunaan narkotika, alkohol, psikotropika, dan zat adiktif lainnya, anak korban penculikan, penjualan dan perdagangan, anak korban kekerasan, baik fisik dan/atau mental, anak yang menyandang cacat, dan anak korban perlakuan salah dan penelantaran.

UU tersebut juga memberikan ancaman sanksi pidana penjara 5 (lima) tahun dan/atau denda Rp. 100.000.000,00 terhadap mereka yang terlibat langsung dengan anak dan juga terhadap mereka yang membiarkan atau tidak memberikan pertolongan kepada anak yang nyata-nyata sangat memerlukan pertolongan. ${ }^{2}$

62Pasal 78 UU Perlindungan Anak tersebut menyatakan: "Setiap orangyang mengetahui dan sengaja membiarkan anak dalam situasi darurat sebagaimana dimaksud dalam Pasal 60, anakyang berhadapan dengan hukum, anak dari kelompok minoritas dan terisolasi, anak yang tereksploitasi secara ekonomi 
Sementara itu, sanksi pidana terhadap tindakan kekerasan atau ancaman kekerasan, atau memaksa anak untuk melakukan persetubuhan dengannya atau dengan orang lain, atau membiarkan tindakan pencabulan terhadap anak maka sanksinya adalah hukuman penjara selama 15 (lima belas) tahun atau denda sebesar Rp. 300.000.000,00 (Pasal 81 Ayat 1 dan 2). Sanksi yang sama juga berlaku bagi setiap orang yang memperdagangkan, menjual, atau menculik anak untuk diri sendiri atau untuk dijual (Pasal 83). Sementara sanksi terhadap setiap tindakan eksploitasi terhadap anak, baik untuk kepentingan ekonomi ataupun seksual adalah pidana penjara selama 10 (sepuluh) tahun atau denda maksimal Rp. 200.000.000,00 (dua ratus juta rupiah).

Berdasarkan paparan dan merujuk pada DUHAM serta peraturan perundang-undangan Indonesia, maka, human trafficking yang di dalamnya mencakup hampir semua tindakan yang merendahkan dan mengeksploitasi manusia, jelas melanggar dan bertentangan dengan hak asasi manusia. Sebab, di dalam human trafficking ini, hak-hak dasariah manusia telah dirampas oleh pihak-pihak yang tidak bertanggung jawab. Para korban telah diperlakukan secara tidak manusiawi (dilecehkan dan dieksploitasi) seperti dijadikan sebagai pekerja seks, pelayan hotel, baby sitter, dan pembantu rumah tangga tanpa ada konpensasi yang jelas. Bahkan, tidak menutup kemungkinan, banyak juga yang mati. Mereka seolah telah menjadi manusia yang tergadai harga diri, kebebasan, dan juga kehormatannya. Oleh karena itu, perdagangan orang masuk katagori kejahatan kemanusiaan, ${ }^{63}$ atau bisa juga disebut sebagai bentuk baru dari perbudakan (perbudakan di abad moderen) ${ }^{64}$ yang harus dilawan dan bahkan dimusnahkan dari muka bumi.

dan/atau seksual, anak yang diperdagangkan, anak yang menjadi korban penyalahgunaan narkotika, alkohol, psikotropika, dan zat adiktif lainnya (napza), anak korban penculikan, anak korban perdagangan, atau anak korban kekerasan sebagaimana dimaksud dalam Pasal 59, padahal anak tersebut memerlukan pertolongan dan harus dibantu, dipidana dengan pidana penjara paling lama 5 (lima) tahun dan/atau denda paling banyak Rp. 100.000.000,00 (seratus juta rupiah).

63Pada Pasal 9 Undang-Undang No. 26 Tahun 2000 tentang Pengadilan Hak Asasi Manusia, dinyatakan bahwa kejahatan kemanusiaan adalah salah satu perbuatan yang dilakukan sebagai bagian dari serangan yang meluas atau sistematik yang diketahui bahwa serangan tersebut ditujukan secara langsung terhadap penduduk sipil, yang di antaranya berupa: (a) perbudakan, (b) pengusiran atau pemindahan penduduk secara paksa; (c) perampasan kemerdekaan atau perampasan kebebasan secara fisik lain secara sewenang-wenang yang melanggar (asas-asas) ketentuan hukum internasional, dan (d) perbudakan seksual, pelacuran secara paksa, pemaksaan kehamilan.

${ }^{64}$ Dalam penjelasan Pasal 9 huruf $\mathrm{c}$ dikatakan bahwa yang dimaksud dengan perbudakan dalam ketentuan ini termasuk perdagangan manusia, khususnya wanita dan anak-anak. Lihat UndangUndang No. 26 Tahun 2000 tentang Pengadilan Hak Asasi Manusia. 


\section{Perdagangan Orang dalam Perspektif Filsafat Hukum Islam}

Secara ideal, Islam dihadirkan oleh Tuhan bagi umat manusia sebagai pembebasan terhadap seluruh bentuk penindasan, tirani, kebiadaban, dan perbudakan manusia. Sebab, manusia menurut Islam dilahirkan dalam keadaan bebas atau suci, sehingga setiap bentuk penindasan, tirani, kebiadaban, dan perbudakan merupakan pelanggaran terhadap hak-hak asasi yang dianugerahkan Tuhan kepada manusia. ${ }^{65}$

Islam sebagai agama universal juga selalu menekankan bahwa antara manusia yang satu dengan manusia yang lain adalah sama dan setara atau sederajat. Pembeda di antara manusia-manusia itu hanya pada ketakwaannya saja. ${ }^{66}$ Hal itu karena pada dasarnya manusia diciptakan dari jenis yang satu (min nafs wāhidah). ${ }^{67}$ Universalitas Islam ini melampaui semua perbedaan manusia meliputi suku, ras, agama, kewarganegaraan, etnis, dan jenis kelamin. Nabi Muhammad saw. bahkan pernah menyatakan bahwa "Tidak ada kelebihan orang Arab atas non Arab, selain karena kepatuhannya kepada Tuhan". Hal ini mengindikasikan bahwa pada dasarnya, manusia di hadapan manusia yang lain adalah sama, setara, dan sederajat. Perbedaan manusia hanya ada di hadapan Tuhan dan hal itu sangat tergantung pada ketakwaannya saja kepada Sang Maha Pencipta. ${ }^{68}$

Islam juga menyatakan bahwa manusia merupakan makhluk Tuhan yang paling terhormat dan paling mulia di muka bumi ini. ${ }^{69}$ Oleh karena itu, tidak ada seseorang atau pihak mana pun yang boleh melecehkan, menodai, mengeksploitasi, memperlakukan secara kasar, dan apalagi memperbudaknya. Sebaliknya, manusia bersifat bebas dan merdeka. Selain itu, agama Islam juga diturunkan untuk melindungi dan membebaskan manusia dari segala bentuk penindasan dan perbudakan.

\footnotetext{
65Salah seorang sahabat Nabi yang juga pernah menjadi khalifah, 'Umar bin Khatțāb, pernah mengungkapkan tentang kemerdekaan manusia ini dalam ucapannya yang sangat terkenal kepada gubernur Mesir, 'Amr bin al-Āṣ: "Sejak kapan kamu memperbudak manusia, padahal para ibu mereka melahirkannya dalam keadaan merdeka?"

${ }^{66}$ QS. al-Hujurāt [49]: 13.

${ }^{67} \mathrm{QS}$. al-Nisā' [4]: 1.

68QS. al-Hujurāt [49]: 13.

${ }^{69} \mathrm{Hal}$ ini ditegaskan Allah di dalam salah satu firman-Nya: Walaqad karramnā banī Ādam/ Sungguh Kami benar-benar telah memuliakan anak keturunan Adam (QS. al-Isrā' [17]: 70).
} 
Syariat Islam, di sisi lain, juga diturunkan untuk mewujudkan kebaikan dan kemaslahatan hidup umat manusia, baik di dunia maupun akhirat. Hal ini secara nyata diakui oleh para ulama dan juris Islam. Al-Ghazzālī dalam AlMustașfã min 'Ilm al-Ușūl menyatakan bahwa tujuan pensyariatan Islam adalah untuk melindungi kepentingan (kemaslahatan) umat manusia, yang meliputi lima hal, (a) hifž al-dīn (melindungi agama/keyakinan), (b) hifzz al-nafs (melindungi jiwa), (c) hifž al-aql (menjaga/melindungi akal-pikiran), (d) hifž alnasl (menjaga keturunan/kehormatan), dan (e) hifz al-māl (melindungi harta benda)..$^{70}$ Hal yang sama juga dinyatakan oleh Abū Isḥāq al-Shāțibī. Di dalam kitab al-Muwāfaqāt fi Ușūl al-Ṣharīah, al-Shāțibī menyatakan bahwa seluruh ketentuan hukum yang disyariatkan Allah adalah untuk menjaga dan mewujudkan kemaslahatan umat manusia, baik di dunia maupun di akhirat.71 Kemaslahatan yang ingin diwujudkan oleh syariat Islam, menurutnya, terbagi ke dalam tiga tingkatan, yaitu ḍarūriyyāt, hạ̄jiyāt, dan tahsininiyyāt atau kamāliyyāt. ${ }^{72}$

Kemaslahatan darūriyyāt atau primer (pokok) merupakan sesuatu yang nisaya. Menurut al-Shāțibī -sebagaimana juga dinyatakan oleh al-Ghazzālī-, ada lima hal yang masuk dalam kategori ini, yaitu hifz al-dīn (menjaga agama), hifz al-nafs (melindungi jiwa), hifž al-'aql (memelihara akal), hifž al-nasl (memelihara keturunan), dan hifz al-māl (menjaga harta benda). Jika kebutuhan darūriyyāt ini tidak terpenuhi maka akan mengancam eksistensi manusia sebagai manusia. Oleh karena itu, setiap hal yang bertentangan dengan kemaslahatan dạūrī, harus dihindarkan. Kemaslahatan hạjïyāt atau sekunder yaitu sebuah kebaikan yang jika tidak terwujud maka tidak akan sampai membahayakan eksistensi manusia, tetapi akan menyulitkan dalam menjalankan ketentuan-ketentuan agama ataupun menjalani kehidupan ini.

\footnotetext{
${ }^{70}$ Abū Hāmid Muhammad ibn Muhammad al-Ghazzālī, al-Mustașfā min 'Ilm al-Ușūl, Juz I (Beirut: Dār Ihyā al-Turāth al-'Ārabī, n.d.), 281. Senada dengan al-Ghazzālī, Ibn Qayyim al-Jawziyyah juga mengatakan: "Syariah dibangun di atas kebijaksanaan dan kepentingan manusia di dunia dan akhirat. Syariah sepenuhnya kemaslahatan, sepenuhnya kebijaksanaan. Setiap hal yang keluar dari kemaslahatan menuju kezaliman, dari kerahmatan kepada sebaliknya, dari kemaslahatan kepada kerusakan, dan dari kebijaksanaan menjadi kesia-siaan bukanlah bagian dari syariah (agama), meskipun diupayakan melalui rekayasa-rekayasa yang sistematis. Lihat Ibn al-Qayyim al-Jawziyyah, I'lām al-Muwaqqi'̄n 'an Rabb al-'Ālamīn, Juz III (Kairo: Maktabah al-Kulliyātal-Azhāriyyah, n.d.), 3.

${ }^{71}$ Abū Ishāàq al-Shātịīi, al-Muwāfaqāt fi Ușūl al-Sharīah, Jilid I, Juz II (Beirut: Dār al-Kutub al'Ilmiyyah, 2005), 7.

${ }^{72} \mathrm{Abū}$ Isḥāq al-Shātịbī.
} 
Keberadaan rukhșah dalam menjalankan ibadah (jama' dan qașr dalam salat) merupakan wujud dari kepedulian syariat terhadap kemaslahatan jenis ini. Kemaslahatan tahsiniyyāt atau tersier yaitu kemaslahatan yang jika tidak terwujud, tidak akan merusak eksistensi manusia dan tidak akan menyulitkannya dalam menjalankan kehidupan ini. Contohnya yaitu berpakaian secara baik, baik menurut agama (menutup aurat) maupun menurut adat atau sesuai dengan perkembangan zaman atau berhias sesuai dengan tuntutan norma dan nilai-nilai agama. ${ }^{73}$

Terkait perdagangan orang, yang secara jelas mengancam eksistensi manusia, seperti eksploitasi, penganiayaan, pemerkosaan, dan bahkan pembunuhan, memperlihatkan bahwa hal itu bertentangan dengan ketentuan syariat Islam dan tujuan keagamaan universal yang ingin mewujudkan kebaikan dan kemaslahatan hidup umat manusia. Perdagangan orang merupakan bagian kejahatan kemanusiaan yang bertentangan dengan HAM dan hukum Islam. Pemerintah telah berusaha keras untuk mencegah dan memberantas praktik ini dengan cara menyusun, mengesahkan, dan membentuk sejumlah peraturan perundang-undangan beserta perangkat-perangkat yang dibutuhkan untuk bisa membatasi, mencegah dan memberantasnya. Namun dalam kenyataannya, praktik ini masih banyak terjadi, khususnya di Indonesia. Oleh karena itu, dibutuhkan kerja sama seluruh komponen masyarakat untuk ikut serta terlibat dalam upaya mencegah dan memberantas praktik perdagangan orang ini.

\section{Simpulan}

Perdagangan orang atau yang lebih populer dengan sebutan human trafficking merupakan kejahatan kemanusiaan yang sangat merugikan orang atau pihak-pihak yang menjadi korbannya. Praktik human trafficking telah memakan banyak korban, baik laki-laki maupun perempuan, dewasa maupun anak-anak dalam jumlah yang sangat besar. Para korban trafficking ini diperlakukan sangat tidak manusiawi, seperti dilecehkan dan dieksploitasi, dijadikan sebagai pekerja seks, pelayan hotel, baby sitter, dan pembantu rumah tangga tanpa ada konpensasi yang jelas. Bahkan tidak menutup kemungkinan banyak juga yang mati. Mereka seolah telah menjadi manusia yang harga dirinya tergadai, kebebasannya terenggut, dan kehormatannya hilang.

\footnotetext{
${ }^{73} \mathrm{Abū}$ Ishāā al-Shāṭibī, 7-8.
} 
Melihat kenyataan ini, praktik human trafficking secara jelas bertentangan dengan prinsip-prinsip dasar hak asasi manusia, melanggar ketentuan perundang-undangan yang berlaku di Indonesia dan juga bertentangan dengan hukum Islam. Sebab ketiganya sama-sama menjamin dan melindungi kebebasan dan kemerdekaan manusia yaitu menempatkan manusia secara sejajar dan sederajat, serta mengutuk segala bentuk tindakan eksploitasi, penganiayaan, dan perbudakan.[a]

\section{BIBLIOGRAFI}

Ardian, Andy. "KPAI: Diskusi Pemetaan Daerah Rawan, Pencegahan dan Penanganan Trafficking dan Eksploitasi Anak di Indonesia." ECPAT Indonesia, 2017. https://ecpatindonesia.org/berita/kpai-diskusipemetaan-daerah-rawan-pencegahan-dan-penanganan-trafficking-daneksploitasi-anak-di-indonesia/.

Astuti, Wahyu Tini. "Perdagangan Perempuan untuk Tujuan Pelacuran: Studi Kasus tentang Perempuan Penjual Minuman di Sepanjang Rel Kereta Api di Jakarta." Universitas Indonesia, 2008.

Departemen Luar Negeri AS. "Laporan Departemen Luar Negeri AS mengenai Perdagangan Manusia tahun 2018," 2018. https://id.usembassy.gov/id/ our-relationship-id/official-reports-id/laporan-tahunan-perdaganganorang-2018/.

Eddyono, Supriyadi Widodo. Perdagangan Manusia dalam Rancangan KUHP. Jakarta: ELSAM bekerjasama dengan The Asia Foundation dan USAID, 2005.

GAATW International Secretariat. "Human Rights in Practice: A guide to assist trafficked women and children - The Global Alliance Against Traffic in Women (GAATW)." gaatw.org, 1999.

al-Ghazzālī, Abū Ḥāmid Muḥammad ibn Muhammad. al-Mustasfā min 'Ilm alUșūl. Beirut: Dar Ihyā at-Turāts al-Ārabi, n.d.

Harkrisnowo, Harkristuti. Laporan Perdagangan Manusia di Indonesia. Jakarta: Sentra HAM UI, 2003.

al-Jawziyyah, Ibn Qayyim. I'lām al-Muwaqqi'̄nn 'an Rabb al-'̄lamīn. Kairo: Maktabah al-Kulliyāt al-Azhariyyah, n.d.

Kitab Undang-Undang Hukum Pidana (KUHP). 
Lembaga Kajian Penelitian dan Pengembangan Pengurus Pusat PMKRI St. Thomas Aquinas. "Telaah Human Trafficking di Indonesia." verbivora.com, 2018. http://www.verbivora.com/2018/04/telaahhuman-trafficking-di-indonesia.html.

Parjoko, Maswita Djaja, dan Soetedjo Yuwono. Penghapusan Perdagangan Orang (Trafficking in Persons) di Indonesia. Kementerian Koordinantor Bidang Kesejahteraan Rakyat, 2005.

Rahayu, Salma Safitri. "Analisis Rancangan Undang-Undang Pemberantasan Tindak Pidana Perdagangan Orang." Jurnal Perempuan, no. 49 (2006).

Riadi, Wahyu. "Implementasi Pencegahan Perdagangan Orang Ditinjau dari Perspektif Pertahanan Negara." Jurnal Strategi Perang Semesta 3, no. 2 (2017): 1-24.

Rosenberg, Ruth. Perdagangan Perempuan dan Anak di Indonesia. Diedit oleh Ruth Rosenberg. Jakarta: USAID, 2003.

RR, Rina Antasari. "Penanganan Tindak Pidana Perdagangan Orang dalam Perspektif Global dan Islam di Sumatra Selatan." Jurnal Intizar 24, no. 1 (2018): 115-40. https://doi.org/10.19109/intizar.v24i1.2184.

al-Shāțibī, Abū Isḥāq. al-Muwāfaqāt fi Ușūl al-Sharīah. Beirut: Dār al-Kutub al'Ilmiyyah, 2005.

Subagyo. "Penanganan Trafficking dan KDRT dalam Berbagai Perspektif." Compas.Com, n.d.

Tim ICCE UIN Jakarta. Demokrasi, Hak Asasi Manusia, dan Mayarakat Madani. Jakarta: Kencana, 2003.

Ubaedillah, A., dan Abdul Rozak. Demokrasi dan Hak Asasi Manusia, dan Masyarakat Madani. Edisi Rev. Jakarta: ICCE UIN Syarif Hidayatullah Bekerjasama dengan the Asia Foundation, 2006.

Undang-Undang No. 1 Tahun 2000 tentang Pengesahan Konvensi ILO.

Undang-Undang No. 23 Tahun 2002 tentang Perlindungan Anak.

Undang-Undang No. 26 Tahun 2000 tentang Pengadilan Hak Asasi Manusia.

Undang-Undang No. 39 Tahun 1999 tentang Hak Asasi Manusia.

Undang-undang Nomor 21 Tahun 2007 tentang Pemberantasan Tindak Pidana Perdagangan Orang.

Yentriyani, Andy. Politik Perdagangan Perempuan. Diedit oleh Gusmiani Islah. Yogyakarta: Galang Press, 2004. 